suggest that, as the nucleus presides over the nutrition of the nerve and muscle, the cause of this peculiarity may be looked for in the nucleus alone. I point out, further, that there are known to be two other peculiarities in the abductor systemnamely, tonus and the absence of a cortical centre. Relying on what seem to me to be good analogies, I treat the last of these as the cause of all the rest, and in this way the peculiarities are made to explain and account for each other. Now Dr. Semon has long since committed himself to another view. He has never, so far as I know, supposed that the delicacy of the abductor system might be resident in its trophic centre, the bulbar nucleus, and he has never hinted that the disadvantage of the nucleas might be ascribed to the want of a cortical connexion. Should anyone attach to his third sentence the inevitable construction that Dr. Semon had considered and rejected or partly adopted the idea of such causation he would, I conceive, be greatly misled. Instead of the comparatively simple explanation that I offer, Dr. Semon supposes that there is an unknown difference of constitution between the adductor and the abductor muscles. He is not less bound to assume that there is another difference between their nerves and a third between their nuclei-to assume, moreover, that such differences have baffled the inquiry of histologists, and that in these particulars, too, the abductor system is a strange and unexampled anomaly. On the grounds of simplicity and probability, and notwithstanding Dr. Semon's great experience and acumen, I cannot hesitate to choose between the two alternatives, his and mine. I refrain from obtruding upon you an analysis of the experiments upon animals under ether. I fail to see that they bave any bearing upon the point at issue. I demur, however, to the use of Bacon's term "crucial" as applied to these experiments. An expedient involving an element of uncertainty so great as that which Dr. Semon himself admitsmamely, that as to whether there is or is not a peripheral ganclionic mechanism - to $\mathrm{my}$ mind invalidates its pretensions to so imposing a title. If to this be added our ignorance of ether effects generally and the numberless chances of error arising from local differences which cannot be taken into account, so far from calling the experiments crucial I am tempted to think that inferences based upon them alone partake largely of the fallacy known as ignotum ex ignotioni.

As regards the abductor function in quiet respiration, the work to which Dr. Semon refers me states the problem, Is it reflex or is it automatic? Dr. Semon says it is reflex. $\mathrm{He}$ does not prove it. His "manifold arguments" are condensed into half a page of generalisations concerning that wonderful deus ex machina $\hat{a}$ the respiratory centre. He submits his conclusions to the test of an experimentapproximately crucial this time-and it fails. In this experiment the afferent path devised by Dr. Semon is removed, and in response to the exigencies of the central system during asphyxia the supposed reflex takes place all the same. I submit that this is not a proof of reflex as opposed to automatic action-rather the contrary, and, as before, I think it more logical to dispense with the hypothetical agency. Dr. Semon objects to the term "over-action"' as equivalent to tonus, yet it is not a bad rendering in English of the Greek word. I do not defend it. $I$ used it as descriptive only, and the comparison it implies refers to the lesser action of the adductors. I cannot admit that it is in this sense pathological. Dr. Semon says that he has not heard the tonus of the sphincters so spoken of ; but, rather, has he heard the laryngeal abductors called sphincters?

I shall maintain the views expressed in my paper in THE LANCET of June 16th, 1894, until more forcible arguments are brought against them.

I am, Sirs, yours faithfully,

Wimpole-street, W., July 1st, 1894. JAMES CAGNEY.

\section{"THE RESULTS OF THE HYDERABAD CHLOROFORM COMMISSION."}

\section{To the Editors of THE LANCET.}

SrRs, - In the otherwise excellent report of my remarks on chloroform at the Royal Medical and Chirurgical Society in THE LANCET of July 7th my rejoinder to Dr. Gaskell has been omitted, and consequently the explanation I give of the discrepancy between his results and those of SurgeonLientenant-Colonel Lawrie appears to have no foundation; but the facts before the society were that in SurgeonLieutenant-Colonel Lawrie's experiments clotting occurred, whereas it did not in those of Drs. Gaskell and Shore. The only explanation of this phenomenon is that the blood in Surgeon-Lieutenant-Colonel Lawrie's experiments had not been so altered as to lose its natural coagulability, whilst it had undergone this alteration in those of Drs. Gaskell and Shore. Although I may have been wrong in believing that Surgeon-Lieutenant-Colonel Lawrie used no peptone at all, yet this error did not affect my argument, since the quantity employed failed to produce the profound physiological changes which it did in the experiments of Drs. Gaskell and Shore.

I am, Sirs, yours truly,

Stratford-place, W., July 9th, 1894. T. IAUDDER BRUNTON.

\section{A REMARKABLE DECISION ON MEDICAL CHARGES BY A COUNTY COURT} JUDGE.

To the Editors of THE LAwCrr.

SIRs,-I should be much obliged by your opinion on the following case, as bearing on the interests of medical practitioners generally :-Last summer I was engaged to attend a patient in her confinement, expected about the end of November, at the fee of a guinea. I was called to her at half-past eleven at night on Nov. 14th, when she was reported to be in labour. I found her suffering from gastric derangement and prescribed some medicine which relieved her. I again saw her on Nov. 16th, when she was better. I was again called after eleven at night on Dec. 18th, when I found her suffering from a similar attack and again sent her medicine which relieved her. I did not hear from her again until Dec. 30th, when at about eleven at night I delivered her with instruments, which were necessitated owing to the weak state of her heart. She progressed favourably for a few days, and then unfortunately developed peritonitis, from which she died on the ninth day. I sent in my account for $15 s$. for the extra visits and medicines previously to the confinement, and also charged a half-guinea extra for the instrumental delivery, and $3 s .6 d$. for a special visit after the patient's death, making altogether $\$ 210 \mathrm{~s}$. This account the husband disputed on the ground of over-charge. Consequently I was obliged to county court him. The case was tried at Bow recently, when, much to my surprise, the judge decided for the defendant on the plea that the guinea paid into court by the defendant corered all attendances from the engagement to the termination of accouchement. I am, Sirs, yours truly,

$$
\text { FAIRPLAY. }
$$

*** We entirely dissent from the judge's decision in this case, and hold strongly that the guinea fee only applies to attendance on a normal labour. Would any superior court rule that such a fee should cover attendance in an intervening attack of small-pox or pneumonia ?-ED. L.

\section{LIVERPOOL.}

(From OUR OWN CoRrespondent.)

The Annual Report of the Medical Officer of Health.

THIs report is always an interesting document, and that for 1893 is no exception to the general rule. It will be remembered that Dr. Stopford Taylor recently retired from the office of medical officer of health, being succeeded by Dr. E. W. Hope, who had for some years held the office of assistant medical officer, and more recently also that of port sanitary medical officer. This report, therefore, is that of both these gentlemen.

The Population of Liverpool.

This is a somewhat unknown quantity. The census of 1891 showed a consicierable decrease, which apparently continues, the number for 1893 being estimated as 510,514, as against 517,145 on July 1st, 1891 , and 517,980 the previous April, when the census was taken. Against this apparent decrease is the remarkable fact that there is a natural increase of population by excess of births over deaths of 13,417 during the three years-viz., of 3921 in 1891, 5087 in 1892 and 4409 in 1893. If this natural increase be added to the estimated decrease of 6631 , a total of 20,048 must 